\title{
第31回日本老年医学会総会記録
}

\section{<教育講演 $>$}

\section{厚生院に打ける高齢者肺炎の現況}

\section{山本 俊幸}

Key words : 高齢者, 肺炎, 誤嬩性肺炎, 微少吸引, 起炎菌

(Jpn J Geriat $27: 537-539,1990$ )

\section{I. 緒言}

高齢者の乯吸器感染症はいずれも難治性の事が多 く, 医療の発達, 化学療法の進歩にもかかわらず致命 率は高く，その上，高齢者は各種の基礎疾患をもち， 呼吸器感染症に罹患し易い。今後, 必然的に老年層の 増加がみられることを考えると, 高齢者の呼吸器の感 染症，なかでも肺炎の占める頻度は増加し，その治療 は重要な課題である。

本稿では，外来診察をしていない病院の性格上，い わゆる hospital aquired の肺炎が中心になるが，高柃 者肺炎の現況として，厚生院における高齢者の肺炎症 例につき, その病理像, 臨床像, 誤嚥による肺炎なら びにに細菌学的に検討した結果などについて述べる。

\section{II. 施設の概要}

厚生院は約 60 年の歴史を持つ 300 名の特別養護老人 ホーム, 80 名の救護施設と 250 床の付属病院からなる複 合施設である。しかし，施設の狭小化と老朽化化によ ク，1982年に新築移転し，医療機器の充実と共に施設 の近代化，一体化など施設が整備された。

\section{III. 病理学的にみた肺资死の頻度}

当院における1965年から1987年まどの23年間の剖検 例 1,465 例の病理直接死因は, 肺炎 $28.9 \%$, 心疾患 $17.3 \%$, 悪性新生物 $15.6 \%$ の順であり, 肺炎死が最も 高頻度であった。年代別にみると，肺炎では年代間に 差を認めないが, 悪性新生物と脳出血は加齡により減 少し, 逆に心疾患は増加していた。

そこで，施設の近代化および環境改善の影響を見る 目的で, 当院が現在地に新築移転した1982年10月を境 に，移転前 5 年間（1978年～1982年）を前期，移転後

Pneumonia in the elderly, T. Yamamoto : 名古屋市厚 生院内科
5 年間（1983年〜1987年）を後期として剖検例の病理 直接死因を比較した。その結果，前期では男131例，女 162例，計293例，平均年齢 80.5 歳，後期では男 137 例, 女176例，計313例，平均年齢82.2歳であり，後期にお ける年齢でやや上昇傾向がみられたが，前期では肺炎 (35.5\%)，心疾患 $(14.4 \%)$, 悪性新生物 $(14.0 \%)$ の 順であり，後期では心疾患 (25.9\%), 肺炎 (25.2\%), 悪性新生物（15.0\%）の順で，後期に打ける肺炎死の 減少と心疾患死の増加が明らかであった。年代別によ ると前期では，悪性新生物死は加龄とともに減少し， 肺炎死は加齢とともに増加していた。 とくに，90歳以 上で心筋梗塞以外の心疾患による死亡の増加が著し かった，後期では，前者之同様に悪性新生物死は加齢 とともに減少し，心疾患による死亡が加跉と共に著し く増加していたが，肺炎死と年齢との間には一定の傾 向はみられず，肺炎死の減少が明らかであった。

\section{IV．高齢者肺炎の臨床像}

1985年 2 月より 1988年 1 月までの 3 年間に当院で観 察し, 経皮的気管内吸引法 (TTA) により, 細菌学的 に検討した高齢者肺炎120例150エピソードを院内発症 肺炎と老人ホーム発症肺炎に分けて比較すると，患者 背景では院内発症肺炎は59名74 ピソード，老人ホー ム発症肺炎は61名76エピソードであり, 院内発症でや や男性が多く，老人ホーム発症では女性がやや多く， 年齢は院内発症群で若干高齢であった。日常生活動作 能力 $(\mathrm{ADL})$ は, 院内発症群で平均 3.2 , 老人ホーム発 症群で平均 5.4 であり, 院内発症群で低值を示し, 約 $80 \%$ が 5 点以下の寝たきり患者であった。これに対し， 老人ホーム発症群では $50 \%$ 強が寝たきり状態であっ た。基礎疾患は全例にみられ，脳血管障害後遺症ある いは脳動脈硬化症が両群共に多く，大腿骨䅡部骨折後 遺症が老人ホーム発症群で，老人性痴呆が院内発症群 で多い傾向がみられた。

臨床症状及び徵候は，院内発症群で咳嗽，ラ音がや 
や少なく，チアノーゼがやや多い傾向にあった。また， 発熱は $37^{\circ} \mathrm{C}$ 末満は両群共に 1 例のみで, $37^{\circ} \mathrm{C}$ の微熱は それぞれ15ないし20\%にみられたが，多くは $38^{\circ} \mathrm{C}$ 以上 であった。

TTAによる検出菌は，院内発症群で黄色ブドウ球 菌，肺炎桿菌，緑膿菌，嫌気性菌が，老人ホーム発症 群では肺炎球菌, インフルェンザ菌が多く検出された。 院内発症群は，全身状態が悪く，肺炎をはじめとする 感染症を繰り返し, 頻回の抗生剂治療による菌交代と 推定され，老人ホーム発症肺炎は市中で生活する一般 老人の生活環境により近く，市中発症肺炎の検出菌に 比較的類似した成績と考号られた。また，高齢者では TTA から口腔内の常在菌之される $\alpha$-溶血性連鎖球菌 とナイセリアが約 $40 \%$ に検出され，基礎疾患の存在や 寝たきり状態などから，口腔内の細菌が下気道に侵入 していることが推察された。

肺炎発症時の検查所見では, 白血球数, 赤沈値, CRP, 総蛋白，アルブミン值は両群間に差はなかったが，高 齢者では赤沈 1 時間值が $80 \mathrm{~mm}$ を越える例が多く，さ らにCRPは $4+$ 以上の例が多くみられた。

免疫学的データでは, IgG, A, M ともに差はなかっ たが, 補体ではC3が院内発症群で有意に低值であり,

C4, CH50に差はなかった.ツベルクリン反応は院内発 症群で平均 $5.3 \mathrm{~mm}$ と低く, $10 \mathrm{~mm}$ 末満の陰性例が 52 例 中 38 例73\%であり，一方，老人ホーム発症群では陽性 例が67例中 29 例 $43 \%$ にみられた。

予後については院内発症群で改善50例，増悪または 陰影の残存したもの 15 例, 死亡 9 例であり，老人ホー 么発症群に比し改善率が低く, 死亡率が高率であった。

従って, 高龄者の院内発症肺炎は, 老人ホーム発症 肺炎に比し, 黄色ブドゥ球菌, 肺炎桿菌, 緑膿菌によ る頻度が高く, 細菌学的にも難治化の一要因と考号ら れ，ッベルクリン反応陰性例も多く，C3 も低值で免疫 能の低下が示唆され，この意味においても院内発症肺 炎が難治性である一つの要因之考号られた。

\section{V. 誤䓵による肺资}

高齢の寝たきり患者においては誤燕による肺炎は致 命率も高く, 予後は不良である。しかし, 明らかな誤 舆のエピソードのある場合よりも silent aspiration, micro aspiration あるいは nocturnal aspiration とい われるェピソードのはっきりしない微小吸引が問題で ある。

そこで，1982年 5 月から1987年 4 月までの 5 年間に おける剖検例中, 誤嚥性肺炎が病理学的に確認された
症例について検討した。

その結果, 誤嚥による肺炎の頻度は326剖検例中肺炎 が直接死因となった 88 例の中で 32 例 $(36.4 \%)$ であり， 男21例，女11例とやや男性に多く，年齢は61歳から99 歳，平均年齢は83.9歳であった。また，31例が寝たき りで，寝たきりの期間は平均 3.4 年であった。

病理組織学的には, 異物, 好中球, 異物巨細胞拈よ び肉芽腫形成など $62 \%$ 症例において新旧の病変が混 在していた。

主な基礎疾患は脳血管障害後遺症が18例（56.3\%） ともっとも多く, ついで心筋梗塞 7 例 (21.9\%), パー キンソン氏病 6 例 $(18.8 \%)$, 大腿骨頝部骨折後遺症 5 例 $(15.6 \%)$ の順であった。

誤嚥性肺炎の発症要因として, 前述の基礎疾患に加 えて, 物理的要因として, 経鼻胃管の留置例が14例 $(43.8 \%)$, 死亡直前の蘇生目的を除いた人工呼吸器の 使用が 6 例 (18.8\%)，気管内插管が 5 例 (15.6\%)で, 気管切開は 3 例 $(9.4 \%)$ であった。身体的要因として 與下障害は20例（62.5\%）にみられたが，生前に明ら かな誤嚥のエピソードが見られた例は13例（40.6\%） にすぎなかった。

そこで, 微小吸引のメカニズムについて, 臨床的に 検討した。

まず，気管切開症例10例で気管切開部からの分泌液 中の細菌と，それらの細菌の由来についてみると，10 例全例で気管切開部より緑膿菌が検出され, 鼻腔から 7 例に，咽頭から10例に緑膿菌が検出された。その他 の菌種についても, 気管切開部と鼻腔, 咽頭で一致し ている症例が多くみられた。この気管切開部からの緑 膿菌の血清型別は, 咽頭由来の緑膿菌と全例で，鼻腔 由来では 10 例中 6 例で一致していた。

次に, 気管切開症例10例に捛いて, 咽頭にピオクタ ニンを塗布した後, 気管切開部からの気道分泌液中に 色素が検出されるか否かについてみたところ，10例中 5 例で, 30 分からおよそ 4 時間後に色素が検出された。

さらに，非気管切開例で気道感染と肺炎を繰り返す 症例に打いて, 鼻腔に $10 \mathrm{ml}$ の気管支造影剂を, 微量注 入器で注入すると, 注入開始後 20 分には気管内に造影 凨がみられ，40分後には明らかに主気管支にまで及ん でいた。

Huxley ら（Am J Med 64：564一-568，1978）は放 射性同位元素をラベルしたインジゥムによるシンチグ ラムでこれを証明し，一般健康成人でも深睡眠時に $45 \%$ ，意識障害のある患者では $70 \%$ の高率で鼻腔から 咽頭を経て下気道に吸引されたと報告している。 
従って, Silent aspiration 即ち, 微小吸引をいかに 予防するのかが今後の課題と考兄られる.

そこで, 誤燕性肺炎発症の物理的要因として最も多 かった経鼻胃管留置例について胃内および口腔内貯留 液の $\mathrm{pH}$ と細菌叢について非留置例と比較してみた。 対象は経鼻胃管留置症例21例, 非留置例11例であり, 年秢および性別には差はなかったが, ADL では留置例 で全例が寝たきり状態であったのに対し, 非留置例で は寝たきり例は僅か 3 例であった。

胃内 $\mathrm{pH}$ は留置群で平均 4.7 , 非留置群では平均 6.0 と非留置群で有意に高値であった。しかし, 一般健康 成人の早朝空腹時の胃内 $\mathrm{pH}$ が 2 ないし 3 前後である ことから見ると, 両群ともにかなり高值であった。 た, 口腔内 $\mathrm{pH}$ は両群間に有為な差を認めなかった。

胃液の細菌培養では, 留置群で肺炎桿菌やエンテロ バクターなどのグラム陰性桿菌と腸球菌の検出頻度が 高く, 一方, 非留置群ではグラム陽性桿菌の検出頻度 が高い傾向がみられた。

胃内 $\mathrm{pH}$ と検出細菌叢の関係は, 肺炎桿菌, エンテロ バクターおよびセラチアなどのグラム陰性桿菌と $\beta$. 溶血性連鎖球菌および腸球菌のグラム陽性球菌は $\mathrm{pH}$ 域の広い範囲で検出されたが, 大腸菌と緑膿菌は株数 が少ないが $\mathrm{pH} 5.0$ 以上で検出され, $\mathrm{pH} 2.5$ 以下の強 度酸性域ではイーストのみが検出された。

口腔内貯留液の細菌培養では, 留置群で21例中 20 例 より緑膿菌が24株, 次いで $\beta$-溶血性連鎖球菌が21株と 多く検出された。 また, 非留置群では常在菌の他に数 株のグラム陰性桿菌やイーストが検出された。

今回対象とした経鼻胃管留置例は高齢で基礎疾患を 有し, 㾛たきり状態の compromised hostであり, 誤 鞇性肺炎や気道感染症を発症しやすいことはよく知ら れたことであり，このような症例の胃内及び口腔内細 菌叢を知ることは, 感染時の薬剤選択上ならびに感染 予防の面からも有意義であると考える。

\section{VI. 細菌学的検討}

当院における1981年から1987年までの過去 7 年間の 喀疢中細菌の推移は, 黄色ブドウ球菌, セラチア, 緑 膿菌の増加と肺炎桿菌, 変形菌の減少がみられた。

また, 剖検肺の培養成績では, 当院が新築移転した 1982年10月の前後で比較すると, 後期は当院に於て第 3 世代セフェム剤が使用され始めた時期と一致する が, 後期において肺炎桿菌, 大腸菌の著しい減少と,
黄色ブドウ球菌, 緑膿菌, ブドウ糖非発酵菌, 真菌の 増加が明らかであり, 前述の喀痰中細菌の推移々類似 した成績が得られ, 繁用されている化学療法剤の影響 を示唆する成績であった。

しかし, 剖検肺の培養成績は治療の結果としての検 出菌であり, また, 喀痰検出菌からの原因菌の決定は 極めて困難であり, 当院においては1985年以降, TTA を採用し，起炎菌の検索を行っている。

そこで，1985年 2 月から1987年 1 月までの 2 年間に 検索した喀痰79検体と TTA 132検体からの分離菌を 比較すると, グラム陰性菌では喀痰で緑膿菌, セラチ アが多く, TTAでは緑膿菌, 七ラチアは減少し, 肺炎 桿菌，インフルェンザ菌が多く検出されて打り，グラ 么陽性菌では黄色ブドウ球菌は両者で大差ないが, 表 皮ブドウ球菌はTTAでは検出されず，喀疢で少な かった肺炎球菌がTTAで多く検出され, 喀疢と TTA で細菌学的に明らかに異なる成績を得た。

すでに述べたように, 院内発症肺炎と老人ホーム発 症肺炎における TTA の成績の比較では, 院内発症群 では緑膿菌, 黄色ブドゥ球菌, 肺炎桿菌の頻度が高く, 一方, 老人ホーム発症群では肺炎球菌, インフルェン ザ菌の検出率が高く,いわゆる community aquired の 肺炎の起炎菌のパターンをとっていた。 また，日常生 活動作の差, 即ち, 寝たきり群と非寝たきり群との比 較においてもほぼ同様の成績が得られている. 更に, いずれの群においても， $\alpha$-溶血性連鎖球菌やナイセリ アなどの口腔内常在菌の検出頻度が高く, 高齢者の下 気道には半数以上に口腔内常在菌が存在していること が明らかであった。

\section{VII. まとめ}

以上，厚生院で観察した高齢者の肺炎の現況につい て報告したが, silent aspirationを含めて誤嬩を如何 に予防するのかが最も重要な問題であり, また, 従来 高齢者の感染症は臨床症状, 臨床所見に乏しいといわ れているが，詳細な観察により何等かの情報が得られ るものと考党ている.

最後に, 呼吸器感染症の起炎菌の決定は極めて困難 であり，特に高齢者では喀痰を喀出できないことが多 く, この様な場合, TTA ならびにそのグラム染色が有 用であることを強調するとともに, 複数菌検出時の問 題ならびに病巣由来菌の決定に有用な抗体感作細菌の 問題など，更に検討を進める必要があると考える。 